\title{
PEREKONOMIAN DUA SEKTOR
}

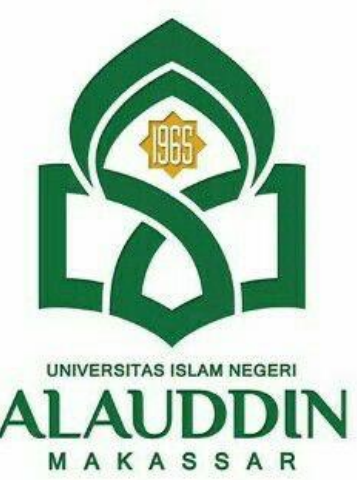

MAKALAH

Pada Mata Kuliah Pegantar Ekonomi Program

Studi Ekonomi Islam Semester I Tahun 2021

Oleh :

Usnul Fadilah

NIM. 90100121101

Dosen Pengajar:

Sirajuddin, ME 


\section{KATA PENGANTAR}

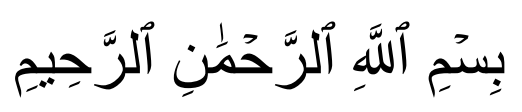

Puji syukur penulis panjatkan ke hadirat Allah swt. Atas rahmat dan hidayah-Nya sehingga penyusunan tesis ini dapat diselesaikan. Shalawat dan salam semoga tercurahkan kepada Nabi Muhammad Saw, keluarga dan para sahabatnya. Makalah dengan judul: "Perekonomian Dua Sektor" ini dimaksudkan untuk memenuhi salah satu syarat lulus pada mata kuliah Pengantar Ekonomi. Penulis menyadari bahwa penyelesaian tesis ini tidak akan terwujud tanpa bantuan, bimbingan dan dukungan dari berbagai pihak.

Makassar, 07 Oktober 2021

Penyusun

USNUL FADILAH 


\section{DAFTAR ISI}

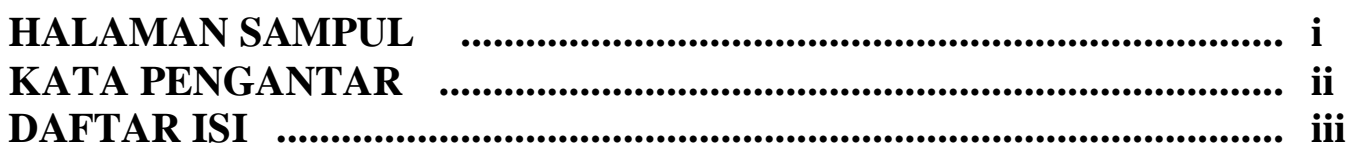

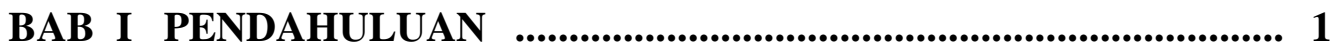

A. Latar Belakang …................................................................... 1

B. Rumusan Masalah ............................................................... 1

C. Tujuan .......................................................................... 2

BAB II PEMBAHASAN ............................................................ 3

A. Perekonomian Dua Sektor ...................................................... 3

B. Hubungan antara Konsumsi dan Pendapatan .............................. 4

C. Fungsi Konsumsi dan Tabungan ................................................ 5

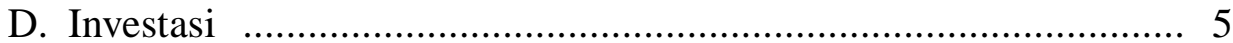

E. Perubahan Keseimbangan dan Multiplier ................................... 6

BAB III PENUTUP …............................................................................. 8

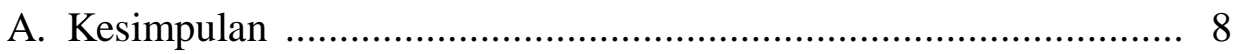

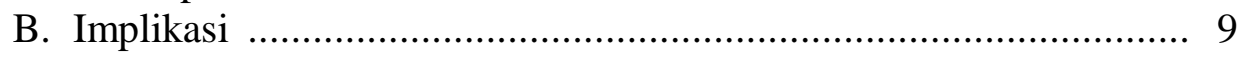

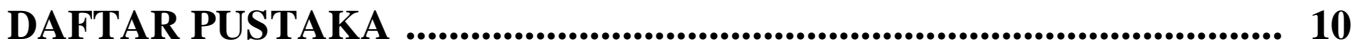




\section{BAB I}

\section{PENDAHULUAN}

\section{A. Latar Belakang}

Perekonomian dua sektor merupakan penyederhanaan dalam mempelajari sistem perekonomian secara keseluruhan. Keseimbangan dalam perekonomian dua sektor merupakan keseimbangan dari sisi pendapatan dan sisi pengeluaran yang dilakukan oleh sektor rumah tangga dan sektor swasta, dengan mengabaikan sektor pemerintah dan sektor luar negeri.

Perilaku pengeluaran yang dilakukan oleh sektor rumah tangga bisa dilakukan dengan membuat fungsi konsumsi dan fungsi tabungan, untuk melihat bagaimana perubahan pendapatan terhadap tingkat pengeluaran konsumsi dan tabungan.

\section{B. Rumusan Masalah}

Adapun sub masalah yang akan dibahas adalah:

1. Apa yang dimaksud dengan perekonomian dua sektor?

2. Bagaimana hubungan antara konsumsi dan pendapatan?

3. Bagaimana fungsi-fungsi konsumsi dan tabungan?

4. Apa yang dimaksud dengan investasi?

5. Bagaimana perubahan keseimbangan dan multiplier? 


\section{Tujuan}

Sejalan dengan rumusan masalah yang telah dituangkan, maka tujuan penulisan ini adalah sebagai berikut:

1. Untuk mengetahui tentang perekonomian dua sektor

2. Untuk mengetahui hubungan antara konsimsi dan pendapatan

3. Untuk mengetahui fungsi-fungsi konsumsi dan tabungan

4. Untuk mengetahui lebih dalam tentang investasi

5. Untuk mengetahui perubahan keseimbangan dan multiplier 


\section{BAB II}

\section{PEMBAHASAN}

\section{A. Perekonomian Dua Sektor}

Perekonomian dua sektor adalah perekonomian yang terdiri dari sektor perusahaan dan sektor rumah tangga. Dalam perekonomian tidak terdapat pajak dan pengeluaran pemerintah. Perekonomian itu juga tidak melakukan perdagangan luar negeri dan dengan demikian perekonomian itu tidak melakukan kegiatan ekspor dan impor.

Dalam perekonomian dua sektor sumber pendapatan yang diperoleh rumah tangga adalah dari perusahaan. Pendapatan ini meliputi gji, upah, sewa, bunga dan keuntungan adalah sama nilainya dengan pendapatan nasional. Dan oleh karena itu pemerintah tidak memungut pajak maka pendapatan nasional (Y) adalah sama dengan pendapatan disposebel ( $\mathrm{Yd}$ ) atau $\mathrm{Y}=\mathrm{Yd}$.

Pendapatan yang digunakan rumah tangga akan digunakan untuk dua tujuan yaitu untuk pengeluaran konsumsi dan ditabung. Tabungan ini akan dipinjamkan kepada penanam modal atau nvestor dan akan digunakan untuk memebeli barang - barang modal seperti mesin - mesin, peralatan produksi lain, mendirikan bangunan pabrik dan bangunan kantor.

Ciri-ciri aliran pendapatan dalam perekonomian dua sektor:

1. Sebagai balas jasa kepada penggunaan faktor-faktor produksi yang dimiliki sektor rumah tangga oleh sektor perusahaan, sektor rumah tangga akan memperoleh aliran pendapatan berupa gaji, upah, sewa, bunga, dan untung. 
2. Sebahagian besar dari berbagai jenis pendapatan yang diterima oleh sektor rumah tangga akan di gunakan untuk konsumsi, yaitu membeli barangbarang dan jasa-jasa yang di hasilkan oleh sektor perusahaan.

3. Sisa dari berbagai jenis pendapatan rumah tangga yang tidak di gunakan untuk pengeluaran konsumsi akan ditabung dalam institusi-institusi keuangan.

4. Pengusaha-pengusaha yang memerlukan modal untuk melakukan investasi akan meminjam tabungan yang dikumpulkan oleh institusi-institusi keuangan dari sektor rumahtangga.

\section{B. Hubungan antara Komsumsi dan Pendapatan}

Terdapat beberapa faktor yang menentukan tingkat kompetisi rumah tangga (secara keseluruhan atau dalam keseluruhan ekonomi). Yang terpenting dalam perekonomian dua sektor adalah pendapatan rumah tangga.

Ciri khas dari hubungan di antara pendapatan disposable, pengeluaran konsumsi dan tabungan, yaitu ;

1. Pada pendapatan yang rendah rumah tangga mengorek tabungan. Rumah tangga harus menggunakan harta atau tabungan masa lalu untuk membiayai pengeluaran konsumsinya.

2. Kenaikan pendapatan menaikkan pengeluaran konsumsi.

3. Biasanya pertambahan pendapatan adalah lebih tinggi daripada pertambahan konsumsi.

4. Pada pendapatan yang tinggi rumah tangga menabung. 
5. Disebabkan pertambahan pendapatan selalu lebih besar dari pertambahan konsumsi, maka pada akhirnya rumah tangga tidak "mengorek tabungan". Ia akan mampu menabung sebahagian dari pendapatannya.

\section{Fungsi Konsumsi dan Tabungan}

Fungsi konsumsi adalah suatu kurva yang menggambarkan sifat hubungan di antara tingkat komsumsi rumah tangga dalam perekonomian dengan pendapatan nasional (pendapatan disposebel) perekonomian tersebut.

Fungsi tabungan adalah suatu kurva yang menggambarkan sifat hubungan di antara tingkat tabungan rumah tangga dalam perekonomian dengan pendapatan nasional (pendapatan disposebel) perekonomian tersebut. Penentu-penentu lain konsumsi dan tabungan:

1. Kekayaan yang telah terkumpul

2. Suku bunga

3. Sikap berhemat

4. Keadaan perekonomian

5. Distribusi pendapatan

6. Tersedia tidaknya dana pensiun yang mencukupi

\section{Investasi}

Investasi (investment) adalah bagian dari tabungan yang digunakan untuk kegiatan ekonomi menghasilkan barang dan jasa (produksi) yang bertujuan mendapatkan keuntungan. Jika tabungan besar, maka akan digunakan untuk kegiatan menghasilkan kembali barang dan jasa (produksi). 
Dari ketentuan di atas dapat ditarik kesimpulan bahwa jika investasi neto positif (investasi bruto lebih besar daripada penyusutan), perekonomian itu mengalami kemajuan. Jika investasi neto bernilai nol (investasi bruto sama dengan penyusutan), dikatakan bahwa perekonomian yang bersangkutan berada dalam keadaan stasioner. Sementara itu, jika investasi neto bernilai negative (investasi bruto lebih kecil daripada penyusutan), perekonomian itu mengalami kemunduran.

Penentu-penentu tingkat investasi :

1. Tingkat keuntungan yang di ramalkan akan di peroleh

2. Suku bunga

3. Ramalan mengenai keadaan ekonomi di masa depan

4. Kemajuan teknologi

5. Tingkat pendapatan nasional dan perubahan-perubahannya

6. Keuntungan yang di peroleh perusahaan-perusahaan

\section{E. Perubahan Keseimbangan dan Multiplier}

Dari satu periode ke periode lainnya, keseimbangan pendapatan nasional akan selalu mengalami perubahan. Dalam perekonomian dua sektor perubahan tersebut disebabkan oleh perubahan dalam investasi. Perkembangan teknologi, misalnya akan menambah investasi dan investasi yang bertambah akan menambah pengeluaran agregat ke atas. 
Analisis mengenai multiplier bertujuan untuk mempengaruhi kenaikan atau kemerosotan dalam mengeluarkan agrerat ke atas keseimbangan dan terutama ke atas tingkat pendapatan nasional. 


\section{BAB III}

\section{PENUTUP}

\section{A. Kesimpulan}

Adapun kesimpulan yang dapat diambil dari makalah ini adalah sebagai berikut :

1. Perekonomian dua sektor adalah perekonomian yang terdiri dari sektor perusahaan dan sektor rumah tangga serta dalam perekonomian tidak terdapat pajak dan pengeluaran pemerintah

2. Hubungan pendapatan dan konsumsi, yaitu besarnya pendapatan sama dengan besarnya konsumsi.

3. Fungsi konsumsi adalah suatu kurva yang menggambarkan sifat hubungan antara tingkat konsumsi rumah tangga dengan pendapatan.

Fungsi tabungan adalah suatu kurva yang menggambarkan sifat hubungan antara tingkat tabungan rumah tangga dengan pendapatan.

4. Investasi adalah bagian dari tabungan yang digunakan untuk kegiatan ekonomi menghasilkan barang dan jasa (produksi) yang bertujuan untuk mendapatkan keuntungan.

5. Dalam perekonomian dua sektor perubahan tersebut disebabkan oleh perubahan dalam investasi. Perkembangan teknologi, misalnya akan menambah investasi dan investasi yang bertambah akan menambah pengeluaran agregat ke atas. 


\section{B. Implikasi}

Demikian pokok bahasan "Perekonomian dua sektor" yang dapat saya paparkan, saya menyadari bahwa makalah ini masih jauh dari kata sempurna karena adanya keterbatasan pengetahuan, referensi, dan tata struktural bahasa dari makalah ini. Oleh karena itu saya mengarapkan saran dan kritik agar makalah ini dapat disusun menjadi lebih baik lagi 


\section{DAFTAR PUSTAKA}

https://anisusanti1982.blogspot.com/2017/12/makalah-perekonomian-2sektor.html?m=1

http://umimauzun.blogspot.com/2018/04/perekonomian-dua-sektor.html?m=1 